\title{
THE EFFECTIVENESS OF THE SALT POLICY IN INDONESIA
}

\author{
Suhendi")1, Asaduddin Abdullah"), and Fithriyyah Shalihati*) \\ *) School of Business, IPB University \\ Jl. Pajajaran, Bogor 16151, Indonesia
}

\begin{abstract}
In general, the goal of a policy is to achieve public welfare through regulations made by the government. Regulations are generally made because they are required to regulate the interests of the communities. Salt is an important commodity demanded by the people in Indonesia. In adition, Indonesia is a country with the second longest coastline in the world; therefore, it has a potential to produce salt and achieve self-sufficiency. However, the national salt production has not been able to meet the demand for salt, especially in meeting the needs for industrial salt. To overcome this problem, the government issued a policy of procuring salt through imports with the hope that industrial needs are met and simultaneously domestic salt production can be increased. The objective of this paper is to analyze the effectiveness of the government policies related to salt by adopting the Regulatory Impact Analysis (RIA) approach. Data and information were obtained through focus group discussions with relevant stakeholders and literature studies analyzed using the RIA approach. The results of this study concluded that the salt policies in Indonesia, especially related to the policy of salt imports, has not been effective. Strategies and corrective actions must be taken so that they can be optimally effective. Strategies that can be carried out include improving the import salt trade system through strengthening the data collection system, monitoring the running of local salt businesses and enforcing laws. The combination between improving the quality of salt produced by the local farmers and guaranteeing the salt prices at the farmer level will accelerate the achievement of the policy objectives.
\end{abstract}

Keywords: self-sufficiency, public policy, imports, farmers, regulatory impact analysis

\begin{abstract}
Abstrak: Secara umum tujuan dari sebuah kebijakan adalah dapat dicapainya kesejahteraan masyarakat melalui peraturan yang dibuat oleh pemerintah. Peraturan umumnya dibuat karena dibutuhkan untuk mengatur kepentingan masayarakat. Garam merupakan salah satu komoditas penting yang dibutuhkan masyarakat di Indonesia. Indonesia merupakan negara dengan garis pantai terpanjang kedua di dunia sehingga sangat potensial untuk memproduksi garam dan tercapainya swasembada. Akan tetapi produksi garam nasional belum mampu memenuhi kebutuhan garam tersebut, terutama dalam memenuhi kebutuhan garam industri. Untuk mengatasi permasalahan tersebut pemerintah mengeluarkan kebijakan pengadaan garam melalui impor dengan harapan kebutuhan industri terpenuhi dan secara simultan produksi garam dalam negeri ditingkatkan. Tujuan dari tulisan ini adalah menganalisis efektivitas kebijakan pemerintah terkait garam dengan mengadopsi pendekatan Regulatory Impact Analisys (RIA). Data dan informasi diperoleh melalui focus group discussion dengan stakeholders terkait dan studi literatur yang dianalisis menggunakan pendekatan RIA. Hasil penelitian ini menyimpulkan bahwa kebijakan garam di Indonesia khususnya terkait kebijakan ketentuan impor garam belum efektif. Strategi dan tindakan perbaikan harus dilakukan agar kebijakan dapat efektif secara optimal. Strategi yang dapat dilakukan diantaranya melalui perbaikan tataniaga garam impor melalui penguatan sistem pendataan, pengawasan terhadap keberjalanan usaha garam lokal dan penegakan hokum. Kombinasi dengan peningkatan kualitas garam petani lokal dan penjaminan harga garam ditingkat petani akan mengakselerasi pencapaian tujuan dari kebijakan.
\end{abstract}

Kata kunci: swasembada, kebijakan publik, impor, petambak, regulatory impact analysis

\footnotetext{
${ }^{1}$ Corresponding author:

Email: suhendi.sbipb@gmail.com
} 


\section{INTRODUCTION}

Salt is a strategic Indonesian commodity whose demand will continue to increase along with an increase in population (Jamil et al. 2017). Indonesia is a country with the second longest coastline in the world with a length of 99,093 kilometers, with salt ponds reaching 26,024 hectares (Munir, 2019). Indonesia has a great potential to produce salt, although not all coastlines can be maximally utilized as a site for salt industry. Therefore, the Indonesian government introduced a salt self-sufficiency program in Indonesia. Salt is not only used for household consumption but also for industrial needs. Consumption salt is generally processed into table salt and dietary salt, while industrial salt is salt used as a raw material in the production process in a number of business sectors. These industriesIndustrial salt include for chemical industries, various food industries, pharmaceuticals, petroleum, leather tanning, and water conservation.

During the period of 2016-2018, the national salt demand experienced an increasing trend, both the need for salt for consumption with an average growth of $1.01 \%$ per year, and the need for salt for industries with an average growth of $10.6 \%$ per year. The total demand for salt in 2018 was 3,679,432 tonnes for industrial salt and 313,848 tonnes for consumption needs (Secretariat General of the Ministry of Marine Affairs and Fisheries, 2019). National salt production has not been able to meet the need for salt, especially in meeting the needs for industrial salt. Domestic production has only been able to supply around $37 \%$ of total demand. Therefore, the government has implemented several policies such as salt procurement through imports. The government issued the Regulation of the Minister of Trade of the Republic of Indonesia Number 63 of 2019 concerning Provisions for Salt Imports. The goal is that the import needs for industries can be met without disrupting the production and trade of salt produced in the country. This regulation is an implementation of the two policies above: Law No.7/2016 concerning the pProtection and eEmpowerment of fFishermen, fFish fFarmers and sSalt fFarmers. It is expected that it will be able to help salt farmers in increasing their production and improving their welfare as well. Furthermore, the government issued the Government Regulation of the Republic of Indonesia Number 9 of 2018 concerning Procedures for Controlling Imports of Fishery Commodities and Salt Commodity as Raw Materials and Industrial Supporting
Materials. In reference to the contents of each policy, it is shown that the objective of these policies is to meet domestic salt needs originating from domestic production or self-sufficiency, and import policies are placed as residuals or cover the deficit in domestic salt needs (consumption and industry) that have not been met from domestic production.

Several researchers have conducted studies related to salt policies in Indonesia. Dharmayanti et al. (2013) found that sustainable self-sufficiency has only been achieved in consumption salt while industrial salt has not been achieved. Increase in the quantity and quality of the farmers' salt and salt conversion need to be implemented simultaneously in Indonesia. Baihaki (2013) further explained that Indonesia has not been able to reduce the amount of salt imports. The government's lack of seriousness can be seen from the lack of coordination between the central government and regional governments in assisting salt farmers. The domestic salt production and price of imported salt have a negative relationship with import volume (Jamil et al. 2017). Al Bram (2016), through his descriptive research, explained that the legal products of their policies have not met the interests of the national salt business actors.

Public policy is a series of conscious, directed, and measurable activities implemented by the government by involving interested parties in certain fields that lead to certain goals (Ramdhani \& Ramdhani, 2017). The goal of a public policy is to achieve public welfare through regulations made by the government. Therefore, the effectiveness of policy implementation is important to study. The effectiveness of the policy issued can be demonstrated by studying its impact on the welfare of the society, especially in accordance with its objectives.

This paperwill explain in more depth the implementation aspects of salt-related policies, especially regarding salt import regulation policy so that the objective of this paper is to analyze the effectiveness of the government policies related to salt using the Regulatory Impact Analysis (RIA) approach. This RIA analysis had not been used by previous researchers. Therefore, it is expected that this paper will be useful for policy makers in seeing the effectiveness of policies issued and for stakeholders related to the development of salt industry in Indonesia. The scope of this study is to analyze 
policies related to salt, especially the Regulation of the Minister of Trade of the Republic of Indonesia Number 63 of 2019 concerning Provisions for Salt Imports.

\section{METHODS}

Types of data and information used in this study included primary data and secondary data. The primary data were in the forms of statements and information obtained from the experts through in-depth interviews and Focus Group Discussions (FGD), and the secondary data were supporting data published by certain institutions. This research was supported by data from various literatures to obtain a basis, explanation and theoretical framework regarding the problem discussed or to seek information that is closely related to the problem formulation, and such data came from the internet (internet searching), articles, and books. The research was conducted in the national scope in the period of 2019-2020.

In-depth interviews and FGDs were conducted with relevant stakeholders including the actors (associations) of salt user industries (APKI, GAPMMI, AIPGI, GPMT, and ASRIM ), salt farmers, the academia (IPB University) and the government (Directorate General of Agro Industry, Ministry of Industry). FGDs were conducted to draw conclusions faster and to have the same agreement and understanding among relevant stakeholders. This was carried out to describe and analyze the existing conditions and problems that occured as well as the alternative solutions in solving these problems based on the perceptions of each field.

The Regulatory Impact Analysis (RIA) was used for the analysis. It is a method for analyzing the impact of a regulation and a fundamental tool to assist the government in assessing the impact of a regulation (Susanto et al. 2016). In conducting an RIA analysis on a policy, whether it is a new policy or an existing one, the OECD (2008) provides the following guidance on the stages of the systematic RIA design process:

1. Formulating the problem.

2. Identifying the objectives.

3. Formulating alternatives.

4. Conducting Benefit and cost analysis.

5. Conducting Public consultation.

6. Choosing the best alternative.

7. Implementing the strategy.
The RIA analysis on the Regulation of the Minister of Trade of the Republic of Indonesia Number 63 of 2019 concerning Provisions for Salt Imports was carried out in this study. However, the issuance of this regulation is inseparable from the Law No.7/2016 concerning the Protection and Empowerment of Fishermen, Fish Farmers and Salt Farmers and from the Government Regulation of the Republic of Indonesia Number 9 of 2018 concerning Import Control Procedures of Fishery Commodities and Salt commodity as Raw Materials and Industrial Supporting Materials. The flow of analysis in this study is shown in Figure 1.

The limitation of this study was that one of the stages in the RIA analysis on the cost benefit analysis for this study was carried out only in a qualitative scope i.e. explaining the existing facts from both the FGD results and literature studies and no quantification was carried out. Only a few facts or indicators could be quantified. The inability to quantify the impact is one of the problems in the cost benefit analysis (Hudiyanto and Retnandri, 2012). However, even though it was qualitative, the cost benefit analysis in this RIA had at least provided initial indications concerning the impact or effectiveness of a policy.

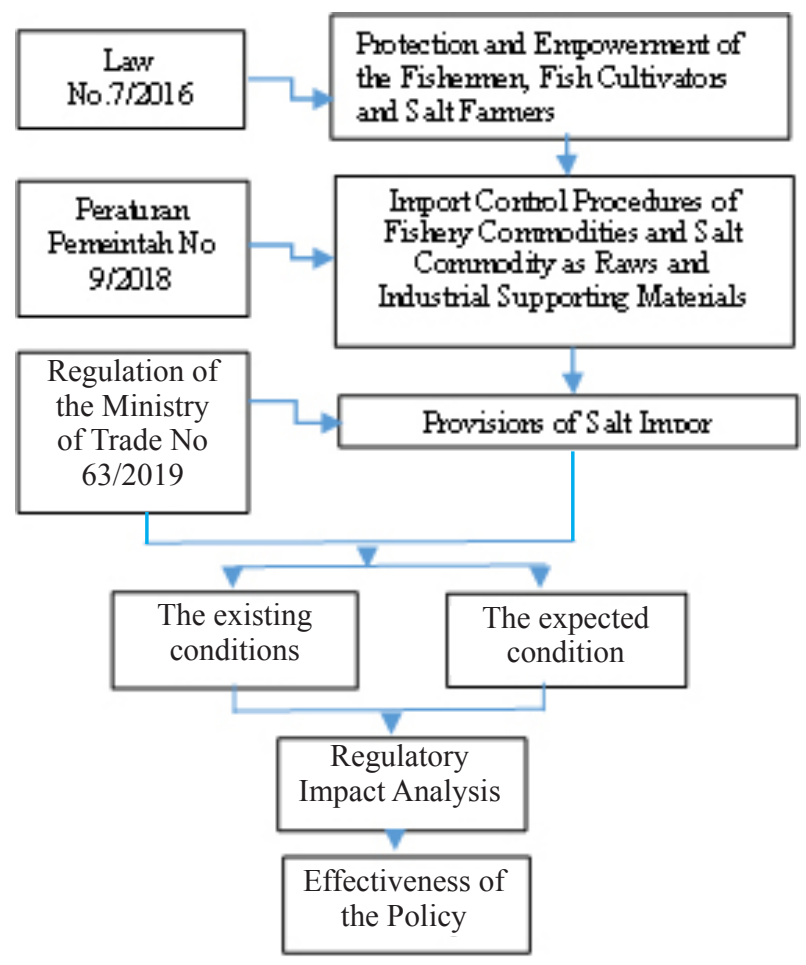

Figure 1. Research framework 


\section{RESULTS}

\section{Salt Related Policy}

The policies related to salt analyzed were the three interrelated policies, namely, Law No.7/2016 concerning the Protection and Empowerment of Fishermen, Fish Cultivators and Salt Farmers, the Government Regulation of the Republic of Indonesia Number 9 of 2018 concerning Procedures for Controlling Imports of Fishery Commodities and Salt commodity as Raw Materials and Industrial Supporting Materials, and the Regulation of the Minister of Trade of the Republic of Indonesia Number 63 of 2019 concerning Provisions for Salt Imports. Further explainations on these policies are as follows:

\section{Law Number 7 Year 2016}

In order to realize the goal of the state in improving the welfare of the people, including fishermen, fish cultivators and salt farmers, the government issued Law Number 7 of 2016 i.e. to carry out Protection and Empowerment of fishermen, fish cultivators and salt farmers in a planned, directed and sustainable manner. This law aims to: a) provide infrastructure and facilities required in developing businesses; $b$ ) provide sustainable businessassurance; c) increase the ability and capacity of fishermen, fish cultivators and salt farmers; strengthen the institutions in managing fish and marine resources as well as in running independent, productive, advanced, modern and sustainable businesses; and develop the principle of environmental sustainability; d) develop financing systems and institutions that serve business interests; e) protect businesses from the risk of natural disasters, climate change, and pollution; and f) provide security and safety guarantees as well as legal assistance.

The scope of the regulation on the Protection and Empowerment of fishermen, fish cultivators and salt farmers includes: a). planning; b) protection; c). empowerment administration; d). funding and financing; e). supervision; and f). society participation.

Government Regulation of the Republic of Indonesia Number 9 of 2018

This government regulation is the implementation of Law Number 7 of 2016 in particular of Article 37. Based on the Government Regulation of the Republic of Indonesia Number 9 of 2018 concerning Procedures for Control of Imports of Fishery Commodities and Salt commodity as Raw Materials and Industrial Supporting Materials, Import Control is implemented in order to ensure the protection and empowerment of fishermen, fish cultivators and salt farmers, and availability and distribution of natural resources for domestic industries. Import control of fishery commodities and salt commodity is implemented by determining the point of entry, type and volume, time of entry, and compliance with administrative requirements and quality standards.

Regulation of the Minister of Trade of the Republic of Indonesia Number 63 of 2019

The Regulation of the Minister of Trade is an implementation of Article 6 of the Government Regulation No.9 of 2018 concerning Procedures for the Import Control of Fishery Commodities and Salt Commodity as Raw Materials and Industrial Supporting Materials and encourages increased national competitiveness and provides business certainty in the import of salt commodity. Salt that can be imported is salt for the fulfillment of industrial raw materials and supporting materials. It can only be imported by a company holding a Business Identification Number (NIB) which is valid as Producer Importer Identity Number (API-P) that has received Salt Import Approval from the Minister.

Salt Import Approval contains data and information concerning: Amounts and types of salt; Tariff Post/HS and description of goods; Loading port; Country of origin; Destination port; and. Validity period of the Salt Import Approval.

\section{Regulatory Impact Analysis (RIA) on Salt Policy in Indonesia}

The following describes the stages in carrying out an RIA analysis.

Formulation of the problem

The issuance of public policies is based on the need to solve problems that occur in the society. Based on the review on policies and information obtained during the FGDs and from the news published in the mass media and electronic media, there were problems related to the need for salt so that the Republic of Indonesia 
Minister of Trade Regulation Number 63 of 2019 was issued. However, the import of this salt must not interfere with the national salt trade system originating from the national production. Therefore, the import of salt is carried out by issuing an import control policy by stipulating the import provisions of salt.

\section{Identification of the Objectives}

The main objective of the issuance of this policy is to control imports of salt commodity. This is conducted in order to ensure the protection and empowerment of salt farmers, as well as to ensure the availability and distribution of natural resources for domestic industries. Therefore, the entry of imported salt is aimed at meeting the needs of the salt user industries, being able to protect salt farmers, providing sustainable business certainty, encouraging national competitiveness, and providing business certainty in the import of salt commodity.

\section{Formulation of Alternative Solutions to Problems}

A public policy will be effective if it is implemented in a planned, consistent manner and has positive benefits for the community (Agindawati, 2019). The Regulation of the Minister of Trade of the Republic of Indonesia Number 63 of 2019 has been running since mid-2019. It is hoped that this regulation will be able to solve the problems mentioned above. Therefore, the alternative solutions to solve the problem are first the continuance of the policy that has been issued. This solution is implemented when this policy has been effective in accordance with the expected goals. Second, improvement of the policies that have been issued. This solution is implemented if the policy has not been effective but can still be improved. Minor improvement is made where some of the goals have been achieved, and improvement is made to improve the achievement of the goals. Third, cancellation of the policy that has been issued. This solution is made if this policy is ineffective and unable to achieve the goals set and has more negative impacts than the positive ones.

\section{Cost and Benefit Analysis}

Benefits contain positive things or benefits for a party while costs are negative things or detrimental to a party if the choice is made. Costs or benefits in this case do not always mean money. Therefore, in the context of identifying the costs and benefits of a policy, it is necessary to identify who is affected and who will benefit as a result of a policy choice (including the fact that the policy taken is to do nothing (Andarwulan, 2015).

Prior to conducting further analysis, stakeholders who were directly or indirectly affected by the policy related to the import of salt were identified. The main stakeholders who received benefits or who would be affected by the policy included: Salt farmers; Importers, in this case, salt importers; The government, in this case, the Ministry of Trade \& Industry and the Ministry of Maritime Affairs and Fisheries; Consumers, in this case, households consuming salt; Salt user industries i.e. industries using salt as one of their raw materials.

To conduct a cost benefit analysis, the authors compared the conditions when there was no policy (doing nothing), current conditions (running the policy) and expected conditions. This comparison was made to show the effectiveness of the policy. If the current condition is better than the condition before the policy was implemented and according to expectations, then the policy can be said to be effective and executable. However, if the current condition is worse, the policy is ineffective and can be reviewed and terminated.

At the initial stage of the analysis, the conditions before the policy was issued were introduced. As it is known, before the existence of this policy, there had been a number of problems. Firstly, the salt user industries experienced lack of salt as a raw material for their products because import permits had not been issued (Kompas, 2019). Secondly, the quality of local salt was lower compared to the imported salt so that it was not absorbed by the industries. Industrial salt must meet certain conditions required by the industries. The salt produced by farmers had a sodium chloride $(\mathrm{NaCL})$ content of less than $94 \%$. Meanwhile, the NaCL level required by the industries is above $97 \%$. The low quality of farmers 'salt resulted in extremely low price i.e. only IDR 300-IDR 500 per kilogram (Warta Ekonomi, 2019). It is suspected that there was a leakage in the sale of industrial salt to the public for consumption salt (Kompas, 2019). Based on the results of in-depth interviews with the head of the salt farmer group, it was found that the ideal price received by salt farmers was IDR 1,500 per kilogram. Thirdly, the farmers' salt production in the community production centers was approximately 2.2 million tons, most of which was still 
not absorbed and unsold. Salt stocks were not balanced by the absorption rate in the market (Pikiran Rakyat, 2019). These conditions and problems were used as a baseline to compare between expectations and conditions after the implementation of the salt import regulation.

Based on the results of in-depth interviews, FGDs, information published in the mass media and electronic media, and after the implementation of the regulation (August 2019-August 2020), the demands of the salt user industries until semester 1 of 2020 had been well fulfilled. Although the potential for shortages can still occur in the second semester of 2020 due to the reduced import quotas or inaccurate salt demand data (Business Economics, 2020). Through the People Salt Business Development Program (PUGAR), the government has also succeeded in improving the quality of the salt to be cleaner, and its $\mathrm{NaCl}$ content has increased by $91 \%$ although it is still far from the standard required by the industries i.e. above 94\%. Currently, 24 National Salt Warehouses have been built, and salt fields covering an area of 2,971 hectares in 24 salt-producing districts and cities have also been integrated (Trubus, 2020). However, the price of salt at the farm level is still low, ranging from IDR 250-600 per kilogram. The yields of the people salt production in the community production centers have not been absorbed. Control policies or product import provisions should decrease the amounts of domestic products in the market and increase their prices (Sulaiman et al. 2018). This is in contrast to the case with salt where the local salt price remains low. The industries cannot absorb it due to the non-conformity of the required standards. The analysis of the costs and benefits of the condition of the full policy operation is shown in Table 1.

The cost benefit analysis as described above was carried out qualitatively. At least, it could describe the indicators of effectiveness or impact of the implementation of the regulation. Based on the cost benefit analysis, it showed that the policy has not been effective. Although the existence of this regulation has provided benefits which improved the conditions before the regulation, the costs (negative impact) incurred are still there; however, it is possible to minimize the costs and make improvements. Minor improvements where some of the goals had been achieved were made to improve the achievement of the objectives. In other words, the current policies have not been fully effective. To make the costs effective, these problems must be resolved immediately.
Conducting Public Consultation \& Choosing the Best Alternative

To find the best alternative, it begins with a public consultation. This study involved related stakeholders through FGDs and joint meetings involving the farmers, industries, academia and government. The result of this public consultation and in reference to the analysis of costs and benefits, the best alternative is to improve the policy that has been issued. Improvement is made by developing strategies and concrete actions that can eliminate or minimize the costs or problems that still exist. Regulation of the Minister of Trade of the Republic of Indonesia Number 63 of 2019 is focused on the provisions of salt imports. However, in reference to the result of the cost benefit analysis, this regulation is closely related to efforts to increase the productivity of salt farmers and the quality of the salt produced.

The steps to increase protection taken by the government by issuing policies are closely related to the philosophy of self-sufficiency economy because the ultimate goal is to enable domestic potential to be more independent and to able to compete. The philosophy allows the country to continue to modernize, not to be anti-globalization but also to prepare itself to ward off negative effects due to economic transitions (Boonkam, 2011). If it is related to the salt sector in Indonesia in facing the entry of imported salt, the self-sufficiency economy as stated above becomes relevant. Indonesia's salt import policy is based on the need for salt which cannot be fulfilled solely by relying on domestic production. Therefore, the self-sufficiency economy emphasizes the need for a mindset of the individuals, the society and the state to realize the need to utilize abundant natural resources for domestic interests. Furthermore, the salt business of the farmers as the basis for managing these resources must receive empowerment from the government, such as access to technology for quality improvement and a trade system that prioritizes their welfare. In doing so, it is possible for the government to partner with the private sectors for investment, especially if they are local business actors (Boenarco, 2012).

The results of the FGDs indicated that in order for a policy to be effectively implemented, the following strategies and actions could be carried out as improvements to policy implementation. Based on the inputs of the stakeholders, the alternative strategies developed for the existence of the policy related to salt commodity can be broadly divided into two: 1) 
Improvement in imported salt trading, and 2) Strategies for improving the quality of salt by the local farmers and for guaranteeing salt prices at the farmer level.

Strategies to improve import salt trading. This can be conducted through the following technical actions:

a. Strengthening the salt demand data collection system so that the data are accurate. The data collection system can be coordinated by the Ministry of
Industry as the ministry is in charge of the salt user industries. The amount of quota that is set depends on the calculation of salt demand for industrial salt users. This list of needs becomes an attachment to the import application submitted to the relevant ministry. Therefore, real and accurate calculations must be made so that scarcity of salt or excess of imported salt does not occur.

Table 1. Analysis of costs and benefits of salt import policy

\begin{tabular}{|c|c|c|c|}
\hline \multirow{2}{*}{ Stakeholders } & \multirow{2}{*}{ Expectations (Objectives) } & \multicolumn{2}{|c|}{ Existing Conditions } \\
\hline & & Positive Impact (Benefits) & Negative Impact (Cost) \\
\hline The Farmers & $\begin{array}{l}\text { - Salt production is increasing } \\
\text { with industry-accepted quality } \\
\text { - High salt prices (as expected) } \\
\text { - Salt production is absorbed by } \\
\text { the markets/industries }\end{array}$ & $\begin{array}{l}\text { - The policy has been able to } \\
\text { support the increase of salt } \\
\text { production to reduce the } \\
\text { amount of imported salt } \\
\text { - The industries have put their } \\
\text { priorities in absorbing salt } \\
\text { produced by the farmers with } \\
\text { the standard set by them }\end{array}$ & $\begin{array}{l}\text { - Prices received by the } \\
\text { farmers are still low (at } \\
\text { harvest period \& high import } \\
\text { products due to incorrect } \\
\text { timing) coupled with high } \\
\text { production costs compared to } \\
\text { other countries and low levels } \\
\text { of productivity } \\
\text { - Imported salt is traded on } \\
\text { the free market causing } \\
\text { the farmers' salt not to be } \\
\text { absorbed by the markets/ } \\
\text { industries }\end{array}$ \\
\hline The Government & $\begin{array}{l}\text { - Salt self-sufficiency can be } \\
\text { achieved } \\
\text { - Growing income from salt- } \\
\text { based industries } \\
\text { - Reduction in illegal trading } \\
\text { - Protection of domestic } \\
\text { products and industries }\end{array}$ & $\begin{array}{l}\text { - Development of new salt } \\
\text { producing areas in Indonesia } \\
\text { - Existence of a policy to } \\
\text { prevent illegal trading } \\
\text { - Procurement of the raw } \\
\text { materials and auxiliary } \\
\text { materials of salt for the } \\
\text { user industries although at } \\
\text { a certain time there are still } \\
\text { shortages }\end{array}$ & $\begin{array}{l}\text { - The requirements of time and } \\
\text { additional costs to obtain real } \\
\text { and accurate industrial salt } \\
\text { demand data required by the } \\
\text { industries } \\
\text { - Leakage of imported salt } \\
\text { being traded on the free } \\
\text { market }\end{array}$ \\
\hline $\begin{array}{l}\text { Raw Materials } \\
\text { for the User } \\
\text { Industries }\end{array}$ & $\begin{array}{l}\text { - Procurement of raw materials } \\
\text { of salt for the industries } \\
\text { - Appropriate and affordable } \\
\text { salt prices } \\
\text { - Development of industries } \\
\text { utilizing raw and auxiliary } \\
\text { materials from salt }\end{array}$ & $\begin{array}{l}\text { - Procurement of the raw } \\
\text { materials and auxiliary } \\
\text { materials of salt for the } \\
\text { industries even though } \\
\text { at certain times there are } \\
\text { still shortages due to late } \\
\text { issuance of import permits or } \\
\text { inaccurate data on demands } \\
\text { - Prices accepted by the } \\
\text { industry are appropriate and } \\
\text { affordable }\end{array}$ & $\begin{array}{l}\text { - At certain times, there are } \\
\text { problems with both imported } \\
\text { and local salt }\end{array}$ \\
\hline The Importers & $\begin{array}{l}\text { - Confirmation of the } \\
\text { quantity and type of goods } \\
\text { imported according to the } \\
\text { accompanying documents } \\
\text { - Avoidance of unfair trade } \\
\text { practices }\end{array}$ & $\begin{array}{l}\text { - Import business is operating } \\
\text { based on the rules } \\
\text { - State revenue is generated } \\
\text { from import activities }\end{array}$ & $\begin{array}{l}\text { - A survey on industrial salt } \\
\text { demand is required }\end{array}$ \\
\hline Consumers & $\begin{array}{l}\text { - Obtaining local consumption } \\
\text { salt with good quality and } \\
\text { affordable price }\end{array}$ & $\begin{array}{l}\text { - Sufficient supply of salt } \\
\text { consumption }\end{array}$ & $\begin{array}{l}\text { - Possibility to obtain lower } \\
\text { quality of consumption salt }\end{array}$ \\
\hline
\end{tabular}


b. Supervision of the running of local salt businesses and imported salt trading. Efforts that can be made include tighter supervision, especially for salt importers. One of the problems that occurs is the weak supervision of salt imports from the government against importers. This has led to the leakage of imported salt which was specifically intended for industries was circulated in the retail market. Strengthening the aspect of supervision is a must. In line with Al Bram's research (2016), it is necessary to increase the supervision of related agencies over the entry of salt imports into Indonesian territory, because an uncontrolled salt import policy can result in excess of salt imports in the domestic market, and this is supported by weak supervision of related agencies over the entry of salt imports into Indonesia

c. Implementing law enforcement. Efforts that can be made include punishing companies that violate the existing provisions in the issued import policy.

Strategies to improve the quality of salt for the local farmers and to guarantee the price of salt at the farmer level. This can be done through the following technical actions:

a. Use of salt production and processing technology. Lack of salt production is the main trigger for the government to import salt, and lack of domestic salt production is due to the weather factor since continuous rain has caused a large number of farmers fail to harvest their production. As a result, local salt production is not sufficient for selfconsumption and industries. Apart from the weather factor, another factor that makes the amount of salt production in Indonesia relatively small is the traditional salt-making process, which relies on the sun and simple tools such as wood scrapers and windmills. In order to be able to harvest, you have to wait at least 10-14 days to 21 days. The government should fix the problems of salt commodity starting from the upstream, one of which is by increasing the use of technology and by improving the production skills of salt farmerss. Therefore, the salt produced by the farmers can be used for industrial needs. So far, industrial salt needs have been met through imports.

b. Strengthening of the Research and Development. If the main problem of industrial salt in Indonesia is the level of sodium chloride $(\mathrm{NaCl})$ which has not been able to reach the figure of 97.4 percent and low salt production during the rainy season, the government should be able to cooperate with scientists, research institutes, and universities to solve the problems.

c. Extensification of salt agricultural land

Demand on salt continues to increase every year; therefore, salt production can no longer rely on the system as it currently exists. In addition to increasing production in the existing salt centers, Indonesia needs to extend land for salt production in a number of potential areas: Cirebon, Sampang, Pati, Indramayu, Sumenep, Rembang, Bima, Demak, Pamekasan, and Surabaya. Currently, there are efforts to fulfill the salt demand for industries, which can be carried out through an extension program of the development of new land, but there is a need for supporting policies so that this extensification program can take place.

d. Pricing Policy

The low price received by farmers is still a problem in developing agricultural businesses. Price-related regulations including subsidies are needed by farmers so that their business can run optimally (Rasmikayati et al. 2020). The government should provide price protection for salt farmers, for example, by determining the lowest price. This will motivate farmers to improve quality of their salt production.

\section{Implementation Strategy}

Implementation is a stage in the public policy process, and it is generally applied after a policy is determined. It is a series of activities in order to deliver the policies that have been set to the public, so that they produce the expected results (Agindawati, 2019). The implementation strategy is highly important in achieving success in policy implementation. A wellconceptualized policy will not be of much use if it cannot be implemented properly; therefore, it is necessary to design an implementation strategy. Strategies that can be carried out are through socialization, implementation of the draft that has been prepared above (compliance) and performance of regular monitoring and evaluation. Communication with interested parties, including the community, is also highly important to obtain significant inputs so that its implementation does not cause great resistance (Suska, 2012). 


\section{Managerial Implications}

Effective policies are the hope of the government as a regulator. The regulation on salt import provisions is the government's effort to protect Indonesian salt farmers and industrial users of salt raw materials. Therefore, the effectiveness of the policy depends not only on the government but also on the roles of other related stakeholders, namely farmers, industry, importers, and consumers. Each stakeholder can play a role following their responsibilities. First, the government can facilitate programs and activities that are in line with the strategy, namely improving the import salt trading system and improving the quality of salt for local farmers as well as guaranteeing the price of salt at the farmer level, such as insurance for farmers' salt prices, assistance, technology assistance, expansion of salt production areas, supervision and law enforcement must be carried out consistently and continuously. The government should be able to create a conducive and just business climate. Second, farmers must continue to improve productivity and salt quality by implementing proper and correct cultivation techniques. Good quality salt will be able to be absorbed by the industry at an appropriate price. Third, industry users of salt raw materials record their salt needs accurately and correctly and prioritize salt from farmers. Accurate data and support for farmers will help prevent illegal trading and chaos in the salt trade in the market. Fourth, the importer conducts trade properly in accordance with the stipulated provisions. The import and distribution of goods in accordance with the regulations will create an atmosphere that is conducive to domestic trade. Fifth, consumers, as salt users, can become smart consumers who take sides with farmers without reducing the need for quality aspects.

\section{CONCLUSIONS AND RECOMMENDATIONS}

\section{Conclusions}

In optimizing the potential of the country so that it becomes more independent and in increasing industrial competitiveness, the government has made efforts to issue policies in the hope that these goals can be achieved. At the implementation level, it is necessary to evaluate the effectiveness of the implementation of the policy. In regards to the policy on salt commodity, the government has issued the law, government regulation and ministerial regulation. The results of the
RIA analysis showed that the implementation of the Regulation of the Minister of Trade of the Republic of Indonesia Number 63 of 2019 concerning Provisions for Salt Imports has not been effective. Strategies and corrective actions must be taken so that the policy can be optimally effective. Strategies and actions must be able to eliminate or minimize the costs or problems that remain. The strategy for improving the import salt trade system through the strengthening of the data collection system, monitoring of the operation of local salt businesses and law enforcement must be carried out by the government in order to achieve the objectives of the policy. Combination between local farmers' salt quality and guarantee of the salt price at the farmer level will accelaerate the achievement of the objectives.

\section{Recommendations}

A policy cannot run effectively without being accompanied by appropriate strategies and actions and supported by relevant stakeholders. Synergy and coordination are a must. Policies must be made in a comprehensive manner that considers the various impacts and interests of various stakeholders. This research has shown the impact that occurs even though it is descriptive and qualitative. This research does not quantify the impact caused by the policy; therefore, further research can be carried out by quantifying the impact comprehensively so that the results obtained can be better.

\section{REFERENCES}

Al Bram HD. 2016. Implikasi liberalisasi perdagangan terhadap sektor garam nasional (studi kasus kebijakan garam impor di Jawa Timur). Litigasi 17(1):3133-3166.https://doi.org/10.23969/ litigasi.v17i1.107.

Agindawati IN. 2019. Implementasi kebijakan publik dari perspektif penyelenggaraan pengawasan. Jurnal Inspirasi BPSDM Provinsi Jawa Barat 10(1):98-105.https://doi.org/10.35880/inspirasi. v10i1.68.

Andarwulan N. 2015. Metode Regulatory Impact Assessment (RIA) UntukImplementasi Kebijakan. Bogor: SEAFAST Center, Departemen Ilmu dan Teknologi Pangan, IPB.

Baihaki L. 2013. Ekonomi-politik kebijakan impor garam indonesia periode 2007-2012. Jurnal Ilmu Sosial dan Ilmu Politik 17(1). 
Boenarco, IS.2012. Kebijakanimpor garam indonesia (2004-2010): implikasi liberalisasi perdagangan terhadap sektor pergaraman nasional [tesis]. Bogor: Fakultas Sosial dan Politik, Universitas Indonesia

Boonkam S. 2011. The sufficiency economy: a thai solution to economic sustainability. http://www. triplepundit.com/ [28 Juli 2020]

Dharmayanti S, Suharno, Rifin A. 2014. Analisis ketersediaan garam menuju pencapaian swasembada garam nasional yang berkelanjutan (suatu pendekatatan model dinamik). Jurnal SosekKP8(1):103-115.https://doi.org/10.15578/ jsekp.v8i1.1201.

Ekonomi Bisnis. 2020. Impor garam dibatasi, industri mamin terancam sulit bahan baku. https:// ekonomi.bisnis.com [16 Augt 2020]

Hudiyanto, Retnandri ND. 2012. Regulatoryimpact analysis: regulasi pasar modern di Kabupeten Bantul. Jurnal Kebijakan dan Administrasi Publik 16(1).

Jamil AS, Tinaprilla N, Suharno. 2017. Faktor-faktor yang memengaruhi permintaan dan efektivitas kebijakan impor garam Indonesia. Buletin Ilmiah Litbang Perdagangan 11(1): 43-68. https://doi. org/10.30908/bilp.v11i1.73.

Kompas.com. 2019. Susi: harga garam petani anjlok karena impor berlebih dan bocor. https://money. kompas.com/ [ 27 Jul 2020].

Kompas.com. 2019. Industri makanan dan minuman kekurangan bahan baku garam, perlukah impor? https://money.kompas.com. [27 Jul 2020].

Munir S. 2019. Garam di Era Impor. Pamekasan: Centre for Developing Islamic Counceling (CDIC) Institut Agama Islam Al-Khairat Pamekasan Madura.

Organisation for Economic Co-operation and Development. 2008. Building an Institutional Framework for Regulatory Impact Analysis,
Guidance for Policy Maker. Paris: OECD.

Pikiran Rakyat. 2019. Tak terserap pasar, puluhan ribu ton garam menumpuk di Jawa Barat. https:// www.pikiran-rakyat.com [28 Jul 2020]

Ramdhani A, Ramdhani MA. 2017. Konsep umum pelaksanaan kebijakan publik. Jurnal Publik 11(2):208-228. https://doi.org/10.35448/jrat. v11i2.4261.

Rasmikayati E, Elfadina EA, Kusumo RAB, Saefudin BR, Supriyadi. 2020. Policy analysis of mango's agribusiness development (a case in Cikedung District, Indramayu Regency). Jurnal Manajemen \& Agribisnis 17(1):52-62. https:// doi.org/10.17358/jma.17.1.52.

Sekretariat Jenderal Kementerian Kelautan dan Perikanan. 2019. Laporan Tahunan 2018. Jakarta: Kementerian Kelautan dan Perikanan RI.

Sulaiman AA, Subagyono K, Hermanto, Suwandi. 2018. Perdagangan Internasional Komoditas Pangan Strategis. Mengangkat Kesejahteraan Petani Pangan Di Era Globalisasi Perdagangan. Jakarta: IAARD PRESS.

Susanto DA, Suprapto \& Hadiyanto J. 2016. Regulatory impact analisys terhadap pemberlakuan standar nasional indonesia biskuit secara wajib. Jurnal Standardisasi 18(3): 217 - 228. https://doi. org/10.31153/js.v18i3.340.

Suska. 2012. Prinsip Regulatory Impact Assessment dalam Proses Penyusunan Peraturan PerundangUndangan Sesuai UU No. 12 Tahun 2011. Jurnal Konstitusi 9(2).

Trubus. 2020. KKP: Kuota impor garam capai 2,9 Juta Ton pada 2020. https://news.trubus.id/. [16 Augt 2020].

Warta Ekonomi.2019. Kualitasgaram lokal rendah picu tingginya garam impor. https://www. wartaekonomi.co.id/ [27 Jul 2020]. 